\title{
Following the tracks of an emerging area: bibliometric analysis of Latin American Political Psychology in the 2000-2010 period *
}

Siguiendo los trazos de un area emergente: análisis bibliométrico de la Psicología Política Latinoamericana en el periodo 2000-2010

Envio 15/12/2013 | Revisión 21/01/2014 | Aceptación 17/07/2014

\author{
LuCILA POLO** \\ JUAN CARLOS GODOY *** \\ DÉBORA IMHOFF **** \\ SILVINA BRUSSINO ****** \\ Universidad Nacional de Córdoba, Argentina
}

doi:10.11144/Javeriana.upsy13-5.ftea

* Para citar este artículo: Polo, L., Godoy, J. C., Imhoff, D., \& Brussino, S. (2014). Following the tracks of an emerging area: bibliometric analysis of Latin American Political Psychology in the 2000. 2010 period. Universitas Psychologica, 13(5), 2047 2057. http://dx.doi.org/10.11144/Javeriana.upsy13-5. ftea

* Equipo de Psicología Política, Laboratorio de Psicología Cognitiva, Facultad de Psicología, Universidad Nacional de Córdoba (Argentina). Enfermera Gordillo esquina Enrique Barros, Ciudad Universitaria. Córdoba (5000), Argentina. Lucila Polo (polo_lucila@hotmail.com), Débora Imhoff (dimhoff@psyche.unc.edu.ar) y Silvina Brussino (brussino9@gmail.com).TE: 543514334176 int. 149

**** Laboratorio de Psicología, Facultad de Psicología, Universidad Nacional de Córdoba (Argentina). Enfermera Gordillo esquina Enrique Barros, Ciudad Universitaria. Córdoba (5000), Argentina. Juan Carlos Godoy (jcgodoy@psyche.unc.edu.ar).TE: 543514333176 int. 171
A B S T R A C T

This study examines contemporary Political Psychology in Latin America, by means of a bibliometric approach, for the period 2000-2010. Results show a steady growth of the field in the region (especially in Spain, Colombia, Mexico, Argentina and Brazil). These countries coincide with the place to which the most productive institutions belong. In turn, the most productive authors of the period are Argentine. The most productive journals concentrate in Spain and Brazil. Finally, a tendency towards individual work, with low levels of collaboration among researchers, is observed. Based on these results, we analyze the current place that Political Psychology has as disciplinary field in Latin America.

Keywords

political psychology; bibliometric analysis; Latin America

\section{RES U MEN}

Este estudio examina la Psicología Política contemporánea en América Latina, a través de un enfoque bibliométrico, para el período 2000-2010. Los resultados muestran un crecimiento constante del campo en la región (sobre todo en España, Colombia, México, Argentina y Brasil). Estos países coinciden con el lugar al que pertenecen las instituciones más productivas. A su vez, los autores más productivos de la época son argentinos. Las revistas más productivas se concentran en España y Brasil. Por último, se observa una tendencia hacia el trabajo individual, con bajos niveles de colaboración entre los investigadores. Con base en estos resultados, se analiza el lugar actual que la Psicología Política tiene como campo disciplinario en América Latina. Palabras clave

Psicología Política; Análisis bibliométrico; Latinoamérica 


\section{Introduction}

Many authors state that, although Political Psychology has been institutionalized and has appeared as such only recently, its origins can be traced back to classical Psychology times (Montero, 2007; Rodríguez Kauth, 2008). In this regard, the majority agrees with the fact that the discipline emerged as such between the First and the Second World Wars, and various publications are available from the 1940s (20th century) onwards (e.g.: Eysenck, 1954; Lasswell, 1948; Maslow, 1943).

The discipline emerged in the United States and in Europe and, gradually, it acquired certain distinctive characteristics, such as its flexibility and the existence of multiple theories and methodologies, both for obtaining data and for confirming hypotheses (Seoane \& Rodríguez, 1990). Given their pioneer character, these regions show a prolific production and they have a strong influence on the topics to be studied and on the way in which they are addressed. However, there is little systematized information with regard to the characteristics that the process of formalization and institutionalization of Political Psychology acquires in Latin America. It can be said that a gradual emergence of productions in the field is observed, which may be promoted by the sustained democracy of the last decades. Maritza Montero wrote the first collections of Political Psychology works in 1987 and 1991. In that regard, Montero (1991) conducted a bibliographic review of the main topics of the discipline in Latin America between 1956 and 1990. Based on her results, Montero considers that the agenda of Political Psychology in Latin America gradually takes shape according to the needs and problems of each place in which it emerges while it tries, at the same time, to build itself. Later, in 2007, Montero presents an important work, which systematizes some relevant historic events of Latin-American Political Psychology. However, her work is only based on study manuals of the area; that is to say, she does not consider journal productions, but manual book productions exclusively. This way, she states that Latin-American Political Psychology starts as an academic systematic discipline in the second half of the 20th century. She emphasizes the importance of the following collections of works (books) in Political Psychology: Montero (1987, 1991), Dorna and Montero (1993), D’Adamo, García, Beaudoux, and Montero (1995), Camino, Lhullier, and Sandoval (1997), Mota Botello (1999) and Oblitas and Rodriguez Kauth (1999) (Montero, 2007). Since then, the production contexts of works in the field marked the development and consolidation trajectories of Latin American Political Psychology.

On the other hand, Parisí (2008) states that one of the characteristics of Latin American Political Psychology is that since its creation it has formed an interdisciplinary field in which the "political" aspect together with the "psychological" aspect are areas in which different branches of knowledge and practice converge.

Moreover, recently some other authors have published works related to Political Psychology's development in different Latin American countries. That way, Brussino, Rabbia, and Imhoff (2010) consider that only with the advent of democracy in the decade of 1980 in Argentina the discipline started to be addressed; therefore, it can be argued that Political Psychology in this country is in an initial development stage. Regarding current research teams that are considered part of this disciplinary field, it can be said that they are relatively few and that they are distributed in different cities of the country: Buenos Aires, Cordoba and San Luis. Also, in 2012 the Psicologia Política Journal (Brazil) has published a special volume, whose scope was the advances and challenges of Ibero-latinamerican Political Psychology. In that volume, we can find a historical review of Political Psychology in Colombia, Brazil, Chile, Peru, Mexico, Venezuela and Portugal. This work was promoted by the Brazilian Association of Political Psychology (Associação Brasileira de Psicologia Politica, ABPP) and the Ibero-Latin American Association of Political Psychology (Asociación Ibero-latinoamericana de Psicología Política, AILPP).

However, and although some studies that go over the agenda have been found in different regions, after a thorough search, no bibliometric studies about Political Psychology in the region have 
FOLLOWING THE TRACKS OF AN EMERGING AREA: BIBLIOMETRIC ANALYSIS OF Latin American Political Psychology in the 2000-2010 Period

been found during the period in which this research was developed. Even more, Montero $(1991,2007)$ does not specify the way in which she carried out her bibliographic review, beyond specifying that she worked with manual books. These aspects emphasize the importance of this study, aimed at knowing, from a bibliometric approach, the status of the academic production related to this disciplinary field in Latin America.

\section{Method and Materials Type of study}

A bibliometric analysis was conducted. This type of work is also known as bibliometric historiographic study and it is included in the ex post facto studies together with other empirical studies with quantitative methodologies (Montero \& León, 2007).

\section{Procedure and data analysis}

A search of articles published in scientific journals within the 2000 - 2010 period was conducted. Books, book reviews, book's chapters and commentaries were not considered for this research. The period was chosen based on the feasibility of the study and on the fact that the publications specialized in Political Psychology in Latin America started in 2001. By Latin America we understand "the group of countries of the American continent in which Romance languages are spoken, specifically Spanish, Portuguese and French" (Real Academia Española, 2001). This included the following countries: Argentina, Uruguay, Paraguay, Chile, Brazil, Bolivia, Peru, Ecuador, Colombia, Costa Rica, Venezuela, Cuba, El Salvador, Guatemala, Haiti, Honduras, Mexico, Nicaragua, Panama and Dominican Republic. In turn, studies conducted by researchers from other countries outside Latin America but whose objects of study were problems and population samples from any of the above-mentioned countries were also considered.

As regards the selected databases, they were chosen because they are some of the most important ones of the academic world, because they have a great concentration of scientific journals, and because they are some of the databases with the longest history in Latin America. According to these criteria, the following databases were selected at first: PsycARTICLES (APA, American Psychological Association), Psychology and Behavioral Sciences Collection (EBSCO), ScienceDirect (Elsevier), Redalyc, Scielo and Dialnet. In addition, and as a verification activity, searches were carried out in some specialized journals (Political Psychology, Psicología Política -Spain, Psicología Política -Brazil and Revista Electrónica de Psicología Política). This procedure was implemented because some of the articles published in those journals did not appear in the selected databases applying the established descriptors.

On the other hand, and with regard to search strategy, we used the review conducted by Sabucedo (1996) and Deutsch (1983) on the list of topics addressed by Political Psychology. The agendas presented by Montero $(1991,2007)$ were also taken into consideration. In this way, the following descriptors/indicators were established:

The individual as political actor: interest in the determining factors and consequences of individual political behavior (political socialization, political participation, individual political behavior, voting behavior, influence of political media. Spanish descriptors: socialización política, participación política, comportamiento político individual, comportamiento de voto, influencia de medios de comunicación política).

Political movements: the unit of analysis are not individuals but groups, not at a formal and institutional level, but in relation to those associations of individuals that interact in order to carry out promotion and control activities or to avoid changes in the socio-cultural environment (social movements, social protest, social activism, political affiliation, collective political action, collective memory, political identity. Spanish descriptors: movimientos sociales, protesta social, activismo social, militancia, acción política colectiva, memoria colectiva, identidad política).

The politician or leader: studies about leaders and political leadership, personality of political men and women, psychobiography and psychohistory (Spanish descriptors: líderes, liderazgo político, 
personalidad de las mujeres y los hombres políticos, psicobiografía y psicohistoria).

Coalitions and political structures: groups referred to politicians, in which the psycho-political processes that act in the formation of those groups (interactions that take place between the actors) and the links between leaders and followers (political system/political changes) are studied (Spanish descriptors: sistema político/cambios políticos, interacciones políticas).

Relationships between political groups: political units of analysis are not persons but nations, international organizations. The most representative line of this category is international conflict (political conflict, terrorism, international conflict, education for peace, political trauma, collective memory, and political violence. Spanish descriptors: conflicto político, terrorismo, conflicto internacional, educación para la paz, trauma político, memoria colectiva, violencia política).

Psycho-political processes: analysis of individual and collective processes implicit in the behaviors of political and public entities affecting them and that are affected by them (perception, cognition, decision-making, learning, political attitudes, social beliefs, values, ideology. Spanish descriptors: percepción, cognición, toma de decisiones, aprendizaje, actitudes políticas, creencias sociales, valores, ideología).

Re-emergence of the study of authoritarianism: with the fall of the Berlin Wall and the political transformations of communist countries, the interest for the study of democratic culture, the stability of democratic systems, nationalisms, patriotism, etc., re-emerges (Spanish descriptors: cultura democrática, estabilidad de los sistemas democráticos, nacionalismos, patriotismo, autoritarismo).

For these descriptors/indicators, exact words and synonyms were considered. Moreover, the word "Political Psychology" was not used isolated, but combined with the descriptors presented above. Information was collected through the assistance of digital media. Once the search was conducted and after confirming that the articles made reference to Political Psychology, relevant controls were carried out to make sure that an article was not counted twice. The total number of articles found in the study period was 639. For the analysis, the statistical package SPSS version 20.0 was used. The following one-dimensional indicators were taken into account: time evolution, production (most productive authors, countries and journals), classification by authors, distribution of works by number of signatures, and collaboration. As regards productivity, time evolution enables to observe if the interest for the discipline increased, remained steady or declined over the years. Also, to examine who are the authors that make more contributions to the discipline, which journal has the greatest number of published articles, and which are the most productive countries. Moreover, the collaboration indicator enables to locate the groups that collaborate in scientific production by means of the identification of joint signatures (Tortosa \& Civera, 2002). Authors consider that the increase number of collaboration is a positive piece of information because it facilitates and broadens the flows of information between researchers, thus having an impact on the quality of the work performed. Although in some other disciplines there are other criteria regarding joint/isolated signatures, this is the one taken into account in this research.

In turn, considering the criteria established by the Journal Catalogue of the Latindex System, the quality of journals with the highest number of articles published in the last decade was analyzed. These criteria were previously agreed upon by a group of specialists of the region of the Latindex System. Moreover, for the journals to be included in the catalogue they must have all the basic characteristics and at least 17 of the other parameters listed. In this way, each journal should have at least $75 \%$ of the established editorial quality characteristics.

\section{Results}

\section{A. Productivity}

A I. Time evolution of Productivity: The total number of articles found was 639. As it can be noted in Graph 1, the greatest production took place in the 
FOLLOWING THE TRACKS OF AN EMERGING AREA: BIBLIOMETRIC ANALYSIS OF Latin American Political Psychology in the 2000-2010 Period

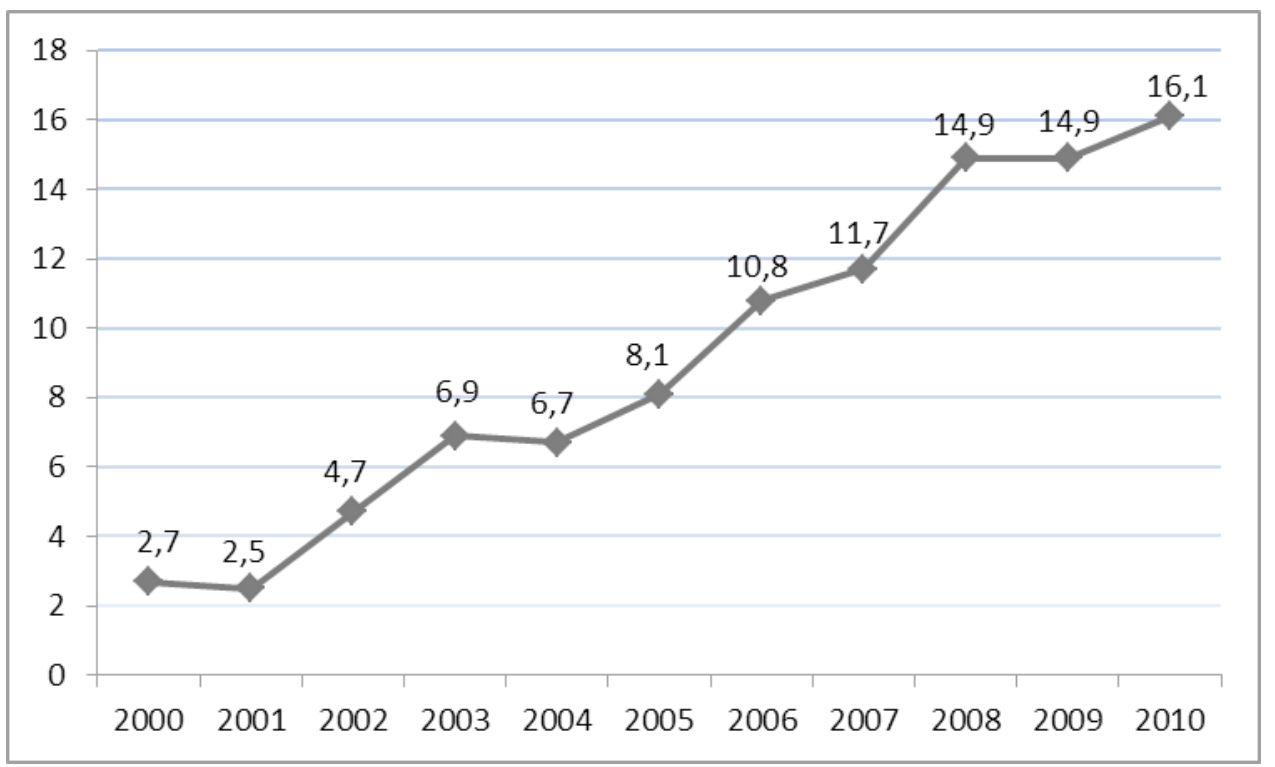

Graph 1

Time evolution of the productivity of Latin American Political Psychology between 2000-2010

last three years of the analyzed period (45.9\%). In this way, in 2010 there were 103 articles (16.1\%), followed by 2008 and 2009 with 95 (14.9\%) each. The year with the lowest number of articles published is 2001, which has only one work less than the previous year $(f=16-2.5 \%)$.

A II. Productivity by Countries of Publication: As regards the most productive countries in relation to publications, the frequency analysis shows that the publications in journals from Spain are in the first place with 120 articles (18.7\%), followed by Colombia with 114 (17.8\%), Mexico with 92 (14.4\%), Argentina with 69 (10.8\%) and Brazil with 62 works $(9.7 \%)$ (see Table 1). Moreover, there is a centralization of publications in a few countries. Surprisingly, Spain - that is not a Latin American country- is among the most productive countries within the studied period. Another interesting piece of information is that there is no connection between the most productive countries and the countries in which the studies reported in the analyzed articles are carried out.

A III. Journals Productivity: In order to observe which journals had more articles published within the analyzed period, a frequency analysis was

\section{TABLE 1}

Production by Countries of Publication

\begin{tabular}{lc}
\hline Countries & $\%$ \\
\hline Spain & 18.7 \\
Colombia & 17.8 \\
Mexico & 14.4 \\
Argentina & 10.8 \\
Brazil & 9.7 \\
Chile & 7.7 \\
Venezuela & 6.1 \\
United States & 3 \\
Peru & 2.7 \\
Costa Rica & 2.2 \\
Ecuador & 1.8 \\
United Kingdom & 1.3 \\
Puerto Rico & 1.3 \\
Denmark & 0.5 \\
Netherlands & 0.5 \\
Germany & 0.5 \\
Portugal & 0.5 \\
El Salvador & 0.3 \\
Uruguay & 0.1 \\
Poland & 0.1 \\
\hline
\end{tabular}

Source: own work 
carried out and then the articles were grouped according to ranges that made it possible to see the regularities of production, and not metric ranges. This showed that journals with the highest number of publications are: Revista de Psicología Política from Brazil with 5\% of the total number of works, América Latina Hoy with 4\% of articles and Psicología Politica with 3.6\% of works, the last two are Spanish journals. On the other hand, the Bradford's law of scattering was analyzed. According to this law, if we consult specialized literature on a particular topic, in this case a discipline, this will be published in a little number of journals, known as core (López López \& Tortosa Gil, 2002). In this way, we were able to know that the core of the discipline is concentrated in the three above-mentioned journals, which concentrate $12.6 \%$ of the total articles published; $87.4 \%$ of the rest of the articles that were part of this review is distributed between 249 journals.

With regard to journals' quality, following the parameters of the Journal Catalogue of the Latindex System, the journals with the highest number of publications were reviewed in order to verify if they complied with the proposed quality criteria. In general, the compliance of the three journals with these criteria is of $80-100 \%$. The journal Revista de Psicología Política (Brazil) complies with 32 criteria, the journal América Latina Hoy complies with 33 criteria and Revista de Psicología Política (Spain) complies with 31 criteria. It is important to bear in mind that these are minimum criteria. It should be noted that two of the three journals that concentrate more articles are journals specialized in this discipline.

Journal Revista de Psicología Política started to be edited in 2001 by the Brazilian Association of Political Psychology (Asociación Brasilera de Psicología Política). Publications are semi-annual; therefore, it has two publications per year with a range from 5 to 11 works per publication. From 2005 until the date of this work, it had a total of 11 publications, in which the acceptance rate was $46.4 \%$ with 769 registered authors. Alessandro Soares da Silva and Celso Zonta, from Universidade de São Paulo and Universidade Estadual Paulista, respectively, are in charge of this journal (Recovered on June 18,
2012 http://www.fafich.ufmg.br/rpp/seer/ojs/statistics.php).

Journal América Latina Hoy is a publication of the Institute of Ibero-America (Instituto de Iberoamérica) and Editions of Universidad de Salamanca and it has been published since 1991. Its aim is to conduct academic analyses of all aspects of the Latin American situation: political, social, historical, cultural and economic. Currently, this journal is edited three times a year with an average of six articles per edition. The current director is Flavia Freidenberg from Universidad de Salamanca (Recovered on June 18, 2012: http://campus.usal. es/ revistas_trabajo/index.php/1130-2887/about).

Furthermore, the first edition of the Spanish journal Revista Psicología Política was in 1990. It is a journal that has two publications per year. It specializes in psychological analysis of political phenomena, with special attention to the problems of political culture and collective action. Although it is possible to send works to be assessed in Spanish, English, Italian and French, they are only published in Spanish or English. The director is Adela Garzón Pérez (Universidad de Valencia). Currently, the journal is edited by Promolibros and it has an average of five articles published per edition (Recovered on June 18, 2012: http://www.uv.es/garzon/).

A IV. Language of Publication: out of 639 articles, 542 (84.8\%) were published in Spanish, 62 (9.7\%) in Portuguese and 35 (5.5\%) in English.

A V. Institutional Productivity by Countries: a frequency analysis was conducted to know if there is also a centralization of institutions, that is to say, if the highest number of publications is concentrated in a little number of institutions, or if, on the contrary, there is a dispersion of production. Results show an institutional condensation, as the countries that have fewer institutions have a greater number of articles produced. Particularly, this happens with Spain, since having only 28 institutions, the country has produced $20.1 \%$ of the total number of articles of the studied period. Even more, Universidad de Alcalá is the most productive institution, with 111 works. This result coincides with the one obtained in the study of Garzón Pérez (2010), which shows that Universidad de Alcalá is one of the most 
productive centers in Spain in the period from 1990 to 2009. As regards the productivity level is followed by Argentina, where the most productive institution is Universidad de Buenos Aires with 61 articles (see Table 2).

A VI. Productivity of authors: At first, a frequency analysis was conducted for every signature number.

TABLE 2

Summary of the Number of Institutions and Productivity by Country

\begin{tabular}{|c|c|c|}
\hline Countries & $\begin{array}{l}\text { Number of } \\
\text { Institutions }\end{array}$ & $\begin{array}{l}\text { \%Total } \\
\text { Production }\end{array}$ \\
\hline Spain & 28 & 20.1 \\
\hline Argentina & 44 & 19.7 \\
\hline Mexico & 29 & 13.7 \\
\hline Colombia & 35 & 12.7 \\
\hline Brazil & 41 & 11.9 \\
\hline Chile & 28 & 7.2 \\
\hline Venezuela & 5 & 3.7 \\
\hline United Kingdom & 9 & 2 \\
\hline Ecuador & 5 & 2 \\
\hline Peru & 4 & 1.9 \\
\hline France & 7 & 0.9 \\
\hline Australia & 1 & 0.9 \\
\hline Bolivia & 3 & 0.7 \\
\hline Netherlands & 3 & 0.3 \\
\hline Cuba & 2 & 0.3 \\
\hline Nicaragua & 2 & 0.3 \\
\hline Canada & 2 & 0.2 \\
\hline United States & 1 & 0.2 \\
\hline Uruguay & 1 & 0.2 \\
\hline Germany & 1 & 0.1 \\
\hline Poland & 1 & 0.1 \\
\hline Belgium & 1 & 0.1 \\
\hline China & 1 & 0.1 \\
\hline Norway & 1 & 0.1 \\
\hline Sweden & 1 & 0.1 \\
\hline Switzerland & 1 & 0.1 \\
\hline New Zealand & 1 & 0.1 \\
\hline Portugal & 1 & 0.1 \\
\hline Austria & 1 & 0.1 \\
\hline Costa Rica & 1 & 0.1 \\
\hline
\end{tabular}

Source: own work
Then, for every signature number, the number of articles written per author was counted. Finally, only with the four most productive authors, the total number of articles was broken down in order to see with which authors they were written. As a result, the three most productive authors in the 2000-2010 period were Ángel Rodríguez Kauth (34 articles), Virginia García Beaudoux (14 articles) and Orlando D'Adamo (14 articles). Out of the 34 works of Rodríguez Kauth, in 33 the author appears as a single signature. All articles are theoretical. On the other hand, all the works published by García Beaudoux and D'Adamo are conducted in collaboration between both authors, and in some cases with other authors. These researchers are part of the same work team. All their articles are reports of empirical studies. Even though the three authors are Argentine, they do not come from the most productive country (Spain). In their respective academic careers they work and/or collaborate at different universities in Spain, which is the most productive country in terms of publication and production.

As we have seen in Table 2, the most productive institutions by country in Latin America are not only from Argentina, but also from Mexico, Colombia and Brazil (see Table 2). That is the reason why we decided to analyze which were the most productive authors from these countries. Results show that Álvaro Díaz Gómez and Nelson Molina are the most productive authors in Colombia; while in Brazil the most productive authors are Lucia Rabello de Castro, Marco Aurelio Máximo Prado and Alessandro Soares da Silva. The case of Mexico is quite different, because its productivity is based on papers from a large number of authors, which have only one or two articles each.

\section{B. Collaboration}

Finally, in order to analyze the degree of collaboration between researchers, the frequencies of the number of authors that signed per article were estimated. Out of a total number of 639 articles, the number of works signed by only one author is 420 (65.7\%). Articles written by one or two authors account for $85.5 \%$ of the total. 


\section{Discussion}

In this study, the status of Political Psychology in Latin America in the 2000-2010 period was analyzed by means of a bibliometric analysis. As regards production over time, and considering previous research (Montero, 1991, 2007), it was possible to note that Political Psychology in Latin America has been undergoing a fluctuation in production. This is because from 1956 to 1973 there were no more than 20 articles published. Later, an exponential growth is observed between 1974 and 1990, with a slight imbalance in the period from 1986 to 1988; then, it decreased again between 2000 and 2001, not exceeding the amount of 20 works published per year. From 2004 onwards, a lengthy growth started to be observed, with the highest number of publications in 2010.

Results obtained show that the countries with the highest level of publication - Spain, Colombia, Mexico, Argentina and Brazil - coincide with the place of origin of the most productive institutions. Secondly, although the most productive authors are Argentine, all of them are related in terms of work and collaboration with Spanish universities. Thirdly, two of the three journals with the highest level of publication are Spanish. This could be explained using the contributions of Garzón Pérez (2010), who states that researchers that publish their work in the Spanish journal Psicología Política - one of the most productive journals - come from different countries, highlighting that it is surprising that there is no predominance of Spanish authors, as it would be expected. Therefore, we can conclude that there is an "internationalization" of publications and that the scientific community is interested to a certain extent in publishing in that country.

This could also be due to the fact that the journals Psicología Política and América Latina Hoy are the oldest and, at the same time, they both make specific and related publications. Another aspect to be highlighted is that, according to the results obtained by Garzón Pérez (2010) and in the case of the most productive journals (América Latina Hoy and Psicología Política), there is a marked interest in knowing what hap- pens in foreign countries, as $15 \%$ of the studies are of Latin American origin.

On the other hand, it may also be noted that there are many European institutions and some North American institutions that conduct studies in Latin America, which would indicate, in addition to what has been mentioned above, a clear and marked interest for the processes that take place in this region. However, it should be noted that $85.5 \%$ of the total production corresponds to works of one or two signatures. This shows the scarce collaboration existing between local institutions and between these and foreign institutions. This coincides with the opinion of Garzón Pérez (2010), who states that in Latin America there is a predominance of individual work. This same study reveals that with regard to the number of signatures of the works conducted in Latin America by researchers from the United States, Canada, Israel, Russia and, to a lesser extent, Europe, they also have a predominance of works with one and/or two signatures. Therefore, we could assert that there is a tendency towards individual work, without the support of work teams or networks in this disciplinary field. In turn, it is necessary to consider that, for bibliometrics, a low number of signatures would mean that this is an emerging research area or an area with a low level of production (Shubert \& Glänzel, 1991).

In this sense, in the coming years it would be interesting to analyze the impact of the recent foundation of the Ibero-Latin American Network of Political Psychology (Red Ibero-latinoamericana de Psicología Politica) (Medellín, 2010) and the Ibero-Latin American Association of Political Psychology (Asociación Ibero-latinoamericana de Psicología Política) (Córdoba, 2011) ${ }^{1}$ in the promotion of networks and research collaboration. These spaces for academic exchange may result in a strengthening of the field and in a better communication between

1 On July 29, 2011 in Medellin the Ibero-Latin American Network of Political Psychology was founded, in the context of the XXXIII Inter-American Congress of Psychology. Later, on November 4, 2011 in Córdoba (Argentina) the Ibero-Latin American Association of Political Psychology was founded, in the context of the $1^{\text {st }}$ Ibero-Latin American Meeting of Political Psychology Groups and Teams. For more information see: http://www.ailpp. org/index.php/institucional 
FOLLOWING THE TRACKS OF AN EMERGING AREA: BIBLIOMETRIC ANALYSIS OF Latin American Political Psychology in the 2000-2010 Period

researchers, with a resulting increase in collective production.

On the other hand, the fact that the highest level of production corresponds to a non-Latin American country may be related to different aspects. On the one hand, the incipient development of Political Psychology in Latin America, related in part to the interruptions in the region's democracy, which resulted in important restrictions for the development of social sciences. In this way, during the coups d'état, the closure of certain academic centers (e.g.: the School of Psychology of Universidad Nacional de Córdoba) was a relevant obstacle for the consolidation of the field. In turn, the continuous political commitment that has been always shown by researchers of the field, as indicated by Seoane and Rodríguez (1990) and Garzón Pérez (2008), was a target of censorship and persecution during dictatorship periods, even resulting in the political exile of many Latin American researchers and intellectuals in different European countries.

On the other hand, what each country invests in research, the gross domestic product (GDP), the economically active population and the number of researchers, among others, are relevant aspects in order to understand this situation. The consideration of these socioeconomic factors provides a view that is closer to the actual status of science, by means of the bibliometric analysis and scientometrics. Further considerations upon these factors would be possible with bibliometric studies of explanatory nature (e.g.: Jaraba-Barrios, Guerrero-Castro, Gómez-Morales, \& López-López, 2011), or with other approaches that integrate categories such as those proposed by Alarcon (2002) and revised by Ardila (2004).

Furthermore, it is also necessary to take into consideration the cultural factors mentioned by Inonu (2003): the influence of education systems, their historical tradition, which are the scientific policies of the government in office, in order to avoid out-of-context interpretations. Moreover, according to Ríos Gómez and Herrero Solana (2005), it can be stated that the GDP (Gross Domestic Product) and scientific production are highly correlated. For this reason, it should be noted that in most Latin American countries there is little investment in the development of scientific research and production, and it is concentrated in the large universities of the most important cities, where the centers of production and development of each country are located.

As regards the low level of publication in Latin American journals, we can find some explanations with regard to the reason why researchers decide not to publish their work in those journals. According to Vessuri (1995), Latin American publications are in a vicious circle. As some national publications may not have international circulation, regional scientists publish their results abroad because national journals do not share their results with the international scientific community or because they are endogamic for the institutions financing the research. In this way, and according to this author, the number of publications that comply with the quality criteria imposed by the ISI (International Statistical Institute) is generally low and, therefore, these publications do not have much impact on the international scientific community. Although it is true that the impact factor should not be the only determining factor of the quality of a journal, as well as of the quality of the researcher's work, it is the criterion that has been agreed as a relevant factor to classify them (Ríos Gómez \& Herrero Solana, 2005), and an important part of the set of Latin American journals included in the ISI generally has a low impact factor.

As a result, those publications are read less frequently and, consequently, their authors are not recognized (Ríos Gómez \& Herrero Solana, 2005). Assuming this situation would lead to the need to strengthen the standards of local journals so as to favor their development and so that they have a greater impact and recognition at an international level. In this way, the exchange of knowledge and experience between local and foreign researchers could be favored, and will help to achieve more international visibility.

Furthermore, if we consider the production of articles of Latin American countries, the countries with the highest number of publications are: $\mathrm{Co}$ lombia, Mexico, Argentina and Brazil. Also, the 
most productive authors come from Argentina. This coincides with the results obtained by Ríos Gómez and Herrero Solana (2005), who argue that according to a collection of the ISI of 53 Latin American titles, the most productive countries are Brazil, Mexico, Chile, Argentina and Venezuela: "these countries account for $80 \%$ of the Latin American total, and the participation of other countries is not significant or they directly lack participation" (2005, p.46). This also coincides with the data obtained by Garzón Pérez (2010), who states that, assessing the origin of the highest number of signatures, there is a predominance of signatures from Argentina, Mexico, Venezuela and Brazil.

Regarding journals' productivity, it should be noted that the number of articles published in journals with only one annual publication is not the same as those that have up to three annual publications. Furthermore, the number of articles published per edition should also be considered. In this sense, the most productive journals have two annual publications and an average of five to eleven works per edition.

Finally, one of the limitations found when conducting the search in the databases was the low accuracy observed on the part of the authors and editors of some scientific journals when establishing parameters for key-words. As a consequence, we found words that did not represent a conceptual entity in themselves and, therefore, it was necessary to search for descriptors in various ways in order to make sure that we were conducting a search as comprehensive as possible. Moreover, it was observed that descriptors were used by different authors and in different regions with different words but with the same meaning. In order to correct this problem, certain words were added to the descriptors chosen at first, as in the case of the words "political affiliation" and "social movements". The correct selection of the key-words of a scientific article is very important, as they are an essential tool when conducting a bibliographic search in databases. Furthermore, their usefulness lies in the fact that they are used to catalogue and index the articles in databases under a particular index or topic. As a result, if the author chooses inadequate key words and the editor of the journals does not notice it, the diffusion of the document, and, as a consequence, its recovery, are hampered due to identification problems. In turn, key words make it possible to analyze works according to the studied topics and see their evolution, and they also provide a thematic deepening that sometimes is not possible if only the title is available (Granda Orive, García Río, \& Callol Sánchez, 2003).

Another limitation is that we found many works of scientific journals that were indexed in the respective databases but did not appear in the search results, not even if they were searched by means of the work's author. Moreover, we found that the same author was registered in up to five different ways according to the different possible ways of writing his/her name.

A final limitation regards the fact that we decided to work exclusively with articles published in scientific journals, excluding from the analysis productions related to books. We took this decision based on the benefits associated to the peer review process and the importance of journals as means through which knowledge is validated and disseminated (Krauskopf \& Vera, 1995). Nevertheless, assumptions related to production of the field in this period should take into account this limitation.

Apart from these limitations, this work has been a first approach to the recent history and development of a new field with high social relevance and a gradual consolidation in Latin America. In the future, it would be interesting to carry out a subject analysis of the works produced, which would offer a deeper approach to the topics studied by Latin American Political Psychology.

\section{References}

Alarcón, R. (2002). Estudios sobre psicología latinoamericana. Lima: Universidad Ricardo Palma.

América Latina Hoy: Revista de Ciencias Sociales. (s. f.). Salamanca: Instituto de Iberoamérica/Ediciones de la Universidad de Salamanca. Recovered from http://campus.usal.es/ revistas trabajo/index.php/1130-2887/index 
FOLLOWING THE TRACKS OF AN EMERGING AREA: BIBLIOMETRIC ANALYSIS OF Latin American Political Psychology in the 2000-2010 Period

Ardila, R. (2004). A psicologia latinoamericana: el primer medio siglo. Interamerican Journal of Psycho$\log y, 38(2), 317-322$.

Brussino, S., Rabbia, H. H., \& Imhoff, D. (2010). Psicología política en Argentina: un recorrido por la historia de una disciplina emergente. Psicologia Política, 10(20), 199-213.

Deutsch, M. (1983). What is political Psychology? International Social Science Journal, 35(2), 221-236.

Eysenck, H. J. (1954). The psychology of politics. London: Routledge \& Kegan Paul.

Garzón Pérez, A. (2008). Teoría y práctica de la psicología política. Información Psicológica, 93, 4-25.

Garzón Pérez, A. (2010). La psicología política veinte años después. Psicología Política, 40, 81-105.

Granda Orive, J. I., García Río, F., \& Callol Sánchez, L. (2003). Importancia de las palabras clave en las búsquedas bibliográficas. Revista Española de Salud Pública, 77(6), 765-767.

Inonu, E. (2003). The influence of cultural factors on scientific production. Scientometrics, 56(1), 137-146.

Jaraba-Barrios, B., Guerrero-Castro, J., Gómez-Morales, Y. J., \& López-López, W. (2011). Bibliometría e historia de las prácticas académicas locales: un esbozo a partir del caso de la psicología en Colombia. Avances en Psicología Latinoamericana, 29(2), 168-183.

Krauskopf, M., \& Vera, M. I. (1995). Las revistas latinoamericanas de corriente principal: indicadores y estrategias para su consolidación. Interciencia, 20(3), 144-148.

Lasswell, H. D. (1948). The analysis of political behavior: An empirical approach. New York: Oxford University Press.

López López, P., \& Tortosa Gil, F. (2002). Los métodos bibliométricos en psicología. In F. M. Tortosa \& C. Civera (Eds.), Nuevas tecnologías de la información y documentación en psicología (pp.199-226). Barcelona: Ariel Psicología.

Maslow, A. (1943). A theory of human motivation. Psychological Review, 50(4), 370-396.

Montero, I., \& León, O. (2007). A guide for naming research studies in Psychology. International Journal of Clinical and Health Psychology, 7(3), 847-862.
Montero, M. (1987). Psicología política latinoamericana. Caracas: Panapo.

Montero, M. (1991). Una orientación para la psicología política en América Latina. Psicología Política, 3, $27-45$.

Montero, M. (2007). La psicología política en América Latina: un estudio comparado. In J. Gissi \& D. Sirlopú (Eds.), Nuevos asedios a la psique latinoamericana (pp. 36-61). Santiago: Ediciones Universidad Católica de Chile.

Parisí, E. R. (2008). Definiendo a la psicología política. Boletín (Sociedad de Psicología de Uruguay. En línea), 46, 20-38.

Psicología Política. (s. f.). Valencia, España: Promolibro. Available at http://www.promolibro.com/revistas. php

Real Academia Española. (2001). Diccionario de la lengua española (22a. ed.). Madrid: Espasa-Calpe. Available at http://www.rae.es/rae.html

Revista Psicologia Política. (s. f.). Sociedade Brasileira de Psicologia Política. São Paulo: Universidade de São Paulo. Available at http://www.fafich.ufmg.br/ rpp/seer/ojs/index.php

Ríos Gómez, C., \& Herrero Solana, V. (2005). La producción científica latinoamericana y la ciencia mundial: una revisión bibliográfica (1989-2003). Revista Interamericana de Bibliotecología, 28(1), 43-61.

Rodríguez Kauth, A. (2008). La investigación y enseñanza en psicología política. Revista Electrónica de Psicología Política, 6(17), 1-11.

Sabucedo, J. M. (1996). Psicología política. Madrid: Síntesis.

Seoane, J., \& Rodríguez, A. (1990). Psicología política. Madrid: Pirámide.

Shubert, A., \& Glänzel, W. (1991). Publication dynamics: Models and indicators. Scientometrics, 20(1), 317-331.

Tortosa, F. M., \& Civera, C. (2002). Nuevas tecnologías de la información y documentación en psicología. Barcelona: Ariel.

Vessuri, H. (1995). Recent strategies for adding value to scientific journal in Latin America. Scientometrics, 34(1), 139-161. 
